\title{
Design Science Research: A Suitable Approach to Scope and Research IT Service
} Catalogs

Schorr, Franziska; Hvam, Lars

Published in:

Proceedings of the 2018 IEEE World Congress on Services (SERVICES)

Link to article, DOI:

10.1109/SERVICES.2018.00026

Publication date:

2018

Document Version

Peer reviewed version

Link back to DTU Orbit

Citation (APA):

Schorr, F., \& Hvam, L. (2018). Design Science Research: A Suitable Approach to Scope and Research IT Service Catalogs. In Proceedings of the 2018 IEEE World Congress on Services (SERVICES) (pp. 25-26). IEEE. https://doi.org/10.1109/SERVICES.2018.00026

\section{General rights}

Copyright and moral rights for the publications made accessible in the public portal are retained by the authors and/or other copyright owners and it is a condition of accessing publications that users recognise and abide by the legal requirements associated with these rights.

- Users may download and print one copy of any publication from the public portal for the purpose of private study or research.

- You may not further distribute the material or use it for any profit-making activity or commercial gain

- You may freely distribute the URL identifying the publication in the public portal 


\section{Design Science Research: A Suitable Approach to Scope and Research IT Service Catalogs}

\author{
Franziska Schorr \\ Global IT \\ DSV A/S \\ Hedehusene, Denmark \\ franziska.schorr@dsv.com
}

\author{
Lars Hvam \\ Engineering Management Department \\ Technical University of Denmark \\ Lyngby, Denmark \\ lahv@dtu.dk
}

\begin{abstract}
Based on the best-practice framework ITIL, an IT service catalog is a system which displays all live IT services but does not manage service requests. Moreover, an IT service catalog also shows how IT services are technically realized. When implementing an IT service catalog as part of the IT service management, firms often struggle with service catalog implementation projects as it requires portfolio-wide information and knowledge about service design, service operations, the customers' use of services, service level agreements and service costing. There is a lack of existing literature on how to design an IT service catalog to fit the individual context and service offerings of companies. This concise paper proposes an approach based on design science for defining the initial design requirements for IT service catalogs. Using this approach in practice resulted in the identification and scoping of the design objectives of IT service catalogs to the needs of individual firms. Moreover, the explorative knowledge on how to design an IT service catalog has been validated by following rigorous research guidelines set out by the design science research method.
\end{abstract}

Keywords-IT service design; IT service management; IT service catalog; design science; design science research methodology

\section{INTRODUCTION}

\section{A. The Motivation for Using an IT Service Catalog}

While the use of IT infrastructure has grown over the years, IT departments may not have a clear picture of the services they are providing and how IT services are adding value to the customer. Making an IT departments' service offerings explicit includes documenting the offered services and how they are being produced and delivered. Documenting IT services regarding its business value and technical specifications is, therefore, a fundamental prerequisite for fact-based IT service management. Hence the Information Technology Infrastructure Library standard (ITIL) proposes to implement an IT service catalog [1]. A service catalog is a knowledge management and communication tool as it transparently outlines the IT services offered to customers by describing the scope, characteristics, and costs of an IT service [2]. A service catalog is usually split into the customer view and the technical view. The customer view provides information on the value a specific IT service offers, often describing the desired functionality of the IT service, or how it can support the customers' business processes or business capabilities. The technical view explains the technical aspects of the IT service delivery including data on both IT-assets (software, hardware, data, network) and IT processes [3].

\section{B. The Relevance of Service Catalog Research}

Even though various examples of IT service catalog models have been published, it is not clear 1) how those models can be applied and implemented at companies, 2) which service catalog scope is relevant for which use of the IT service catalog [4], and 3 ) if a standard IT service catalog could be even suitable to the contexts and needs of different firms [5]. Therefore, practitioner guides describe that the implementation of an IT service catalog can become an exasperating experience [6].

Existing research on IT service catalogs lacks examples of methods suited to describe the planning, designing, building, implementation, and use of a service catalog [4]. Service catalog theories do not explain how IT service catalogs can be scoped suited to the users' requirements [5].

Design science research results in prescriptive knowledge in form of IT artifacts [7] and has been widely applied to information systems research [8]. As an IT service catalog is an IT artifact, a rigorous design science research process could be applied to create prescriptive knowledge.

Therefore, this article proposes to apply a design sciencebased approach for designing IT service catalogs. In the following sections, this approach will be presented and the application and evaluation of the approach in industry will be explained. Finally, the findings from using the approach will be presented and discussed.

\section{RESEARCH METHOD}

IT service catalog research aims to build and evaluate IT service catalog-related constructs, methods, models, and instantiations [9]. Existing theories on design science research methodology and design of IT service catalogs provided the knowledge base for developing this approach.

\section{A. Design Science-Based Approach for Designing IT Service Catalogs}

Only when IT service catalog implementation projects are researched by following rigorous guidelines over the course of the project, valid research results can be obtained [8]. Following design science research guidelines [8], design science research on IT service catalogs must include 
- Designing an IT artefact (constructs, methods, models or instantiations)

- $\quad$ Solving a relevant organizational problem,

- Evaluation of IT artifact,

- Research contributions,

- Application of rigorous methods,

- Communication of research.

A design science research process usually includes the research following activities 1) problem identification, 2) design of the artifact, 3) implementation of the artifact and 4) use and communication of the artifact, and evaluation steps between the activities [10]. To test, evaluate and validate the respective research activities associated with the design of an IT service catalog, a build - ex-ante evaluation concept described by Sonnenberg and Brocke can be used [7]. The evaluation concept defines how to evaluate every research activity before proceeding with the following research activities.

\section{B. Application and Evaluation of the Proposed Approach}

The design science approach was applied at a transportation and logistics service company to define the initial design requirements of an IT service catalog. Using a design science approach for deriving requirements for an IT service catalog is justified because it is part of the design phase of creating an IT service. During workshops with high user involvement of stakeholders, the design requirements for the service catalog such as information content and use of the catalog were identified. As recommended by Hevner et al. an observational case study was conducted afterwards to study the relevance of the findings in a business context [8]. Expert interviews were conducted to test if the identified initial design requirements for IT service catalogs were applicable to the problem of designing an IT service catalog and suitable for the specific needs of the stakeholders of the IT service catalog.

\section{RESULTS}

By applying the design science-based approach, the initial design problem and design objectives for an IT service catalog got refined due to the high user involvement in developing IT service catalog requirements. More specifically, the stakeholders of the IT service catalog aligned their requirements and scoped the catalog regarding

- The motivation and vision for implementing an IT service catalog,

- The structure and content of an IT service catalog, and

- $\quad$ The expected use of an IT service catalog.

Conducting such an explorative approach to design an IT service catalog also contributed to refining existing IT service catalog theory. It became evident that the stakeholders of the IT service catalog initially did not have a common understanding of what an IT service is. The definition of IT services, however, builds the foundation for many IT service management functions, including the definition of actionable service level agreements and IT service costing. Defined and structured IT service offerings are therefore important prerequisite requirements for designing a suitable IT service catalogs.

While ITIL uses IT service catalogs as one of the leading tools to support IT service management, IT service catalogs strongly depend on predefined IT services and IT service management knowledge.

\section{CONCLUSION}

This article proposes a design science-based approach to design IT service catalogs. Testing the approach in a company led to a proactive and successful scope determination of the initial design of an IT service catalog. The results furthermore stated the dependency of IT service catalogs on rigorously defined IT services.

\section{FUTURE RESEARCH}

The approach can be further tested on other service catalog research activities, for instance during the building, implementation, and use of the IT service catalog. Research on IT service ontology is needed to advance IT service catalog research, as IT service catalogs are highly dependent on the definition, structure, representation, and use of IT services. It is proposed to conduct a further literature review on IT service definitions used in the operations management context.

\section{REFERENCES}

[1] L. Hunnebeck, C. Rudd, and S. Lacy, "ITIL Service Design," TSO, London, 2011.

[2] W. T. Dumoulin, B. Fine, and R. Flores, Defining IT Success Through The Service Catalog. Van Haren, 2007.

[3] F. Nord, R. Dörbecker, and T. Böhmann, "Structure, content and use of IT service catalogs - Empirical analysis and development of a maturity model," in Proceedings of the Annual Hawaii International Conference on System Sciences, 2016, vol. 2016-March, pp. 1642-1651.

[4] V. Nissen, D. Jung, M. Petsch, and C.-P. Präg, "Recommendations for a general IT service catalogue structure,” Enterp. Model. Inf. Syst. Archit., vol. 10, no. 1, pp. 89-108, 2015.

[5] M. Arcilla, J. A. Calvo-manzano, and T. San, "Building an IT service catalog in a small company as the main input for the IT financial management," Comput. Stand. Interfaces, vol. 36, pp. 42-53, 2013.

[6] M. O’Loughlin, The Service Catalog. Van Haren, 2010.

[7] C. Sonnenberg and J. Brocke, "Reconsidering the buildevaluate pattern in design science research," in International Conference on Design Science Research in Information Systems, 2012, pp. 381-397.

[8] B. A. R. Hevner, S. T. March, J. Park, and S. Ram, "Design science in information systems research,” MIS Q., vol. 28, no. 1, pp. 75-105, 2004.

[9] S. T. March and G. F. Smith, "Design and natural science research on information technology,” vol. 15, pp. 251-266, 1995.

[10] K. Peffers, T. Tuunanen, M. A. Rothenberger, and S. Chatterjee, "A design science research methodology for information systems research,” J. Manag. Inf. Syst., vol. 24, no. 3, pp. 45-77, 2007. 